\title{
Use of Multivariate Statistics in Order to Understand the Flow of Acid Rock Drainage from an Abandoned Mining Site
}

\author{
Mattias Bäckström1, Lotta Sartz ${ }^{1,2}$ \\ ${ }^{1}$ Man-Technology-Environment Research Centre, Örebro University, Örebro, Sweden \\ ${ }^{2}$ Bergskraft Bergslagen AB, Kumla, Sweden \\ Email: mattias.backstrom@oru.se, lotta.sartz@oru.se
}

Received 18 January 2016; accepted 23 February 2016; published 26 February 2016

Copyright (C) 2016 by authors and Scientific Research Publishing Inc.

This work is licensed under the Creative Commons Attribution International License (CC BY).

http://creativecommons.org/licenses/by/4.0/

(c) (i) Open Access

\begin{abstract}
Pathways for acid rock drainage from an abandoned mining site (sulphidic ore) were investigated by analysing ground, seepage and surface waters. It was found that in affected ground and seepage waters $\mathrm{pH}$ was lower (average $\mathrm{pH}$ 5.0); sulphate higher (average $350 \mathrm{mg} / \mathrm{L}$ ) and trace element concentrations were significantly increased $(4330 \mu \mathrm{g} / \mathrm{L}$ copper and $7700 \mu \mathrm{g} / \mathrm{L}$ zinc) compared to surrounding waters. Multivariate statistics (principal component analysis) were used on the data set. Obtained loading plot showed a clear negative correlation between $\mathrm{pH}$ and parameters found at high concentrations, indicating that these parameters are found at the source term (acid rock drainage). Lead was also found in close proximity to iron and turbidity indicating that lead might be associated with particles. The score plot presented almost all samples from high concentrations to low concentrations along the first principal component (explaining $63 \%$ of the variation in the data set) indicating that dilution was an important mechanism for the decrease in concentrations as opposed to immobilisation on surfaces along the flowpath. Decrease in fluoride and sulphate along one of the suspected flowpath coincided with an increase in calcium. Through geochemical calculations it was concluded that calcite $\left(\mathrm{CaCO}_{3}\right)$ dissolved along the flowpath and thus induced precipitation of gypsum $\left(\mathrm{CaSO}_{4}\right)$ and fluorite $\left(\mathrm{CaF}_{2}\right)$. Through a combination of PCA and geochemical calculations the most likely flowpaths for contaminated water from the abandoned mining site were presented, making it possible to prevent further negative effects on the surface water.
\end{abstract}

\section{Keywords}

PCA, PHREEQC, Metals, ARD, Flowpath 


\section{Introduction}

\section{Chemical Processes}

Mining waste and the generated acid rock drainage containing sulphuric acid and trace elements constitute a serious threat to surface waters in regions with mining. In order to be able to effectively minimize the impact from mining waste it is important to find, understand and treat the major paths for the contaminant water from source to receptor.

The most common sulphides in ore are pyrite $\left(\mathrm{FeS}_{2}\right)$ and pyrrhotite $(\mathrm{FeS})$. Weathering of sulphides in the presence of oxygen generates, primarily, ferrous iron, sulphate and acidity, as for the cases of pyrite and pyrrhotite (Equations (1) and (2) below).

$$
\begin{gathered}
\mathrm{FeS}_{2}(\mathrm{~s})+3.5 \mathrm{O}_{2}+\mathrm{H}_{2} \mathrm{O} \rightarrow \mathrm{Fe}^{2+}+\mathrm{SO}_{4}^{2-}+2 \mathrm{H}^{+} \\
\mathrm{Fe}_{0.9} \mathrm{~S}(\mathrm{~s})+1.9 \mathrm{O}_{2}+0.1 \mathrm{H}_{2} \mathrm{O} \rightarrow 0.9 \mathrm{Fe}^{2+}+\mathrm{SO}_{4}^{2-}+0.2 \mathrm{H}^{+}
\end{gathered}
$$

As Equation (1) proceeds and generates ferrous iron, the ferrous iron is further oxidized according to Equation (3). The following precipitation reactions of ferric hydroxides (Equation (4)) are highly acid producing. This so called latent acidity generally takes place as the leachates leave the deposit and are supplied with oxygen.

$$
\begin{gathered}
\mathrm{Fe}^{2+}+0.25 \mathrm{O}_{2}(\mathrm{aq})+\mathrm{H}^{+} \rightarrow \mathrm{Fe}^{3+}+0.5 \mathrm{H}_{2} \mathrm{O} \\
\mathrm{Fe}^{3+}+3 \mathrm{H}_{2} \mathrm{O} \rightarrow \mathrm{Fe}(\mathrm{OH})_{3}(\mathrm{~s})+3 \mathrm{H}^{+}
\end{gathered}
$$

Equation (3) is hence the kinetically limiting reaction for pyrite weathering; however iron- and sulphideoxidizing bacteria, such as Acidithiobacillus ferrooxidans, Leptospirillum ferrooxidans and Acidithiobacillus thiooxidans are capable of acquiring energy from the oxidation processes of sulphide minerals and ferrous iron [1].

In historic mine waste, where weathering has been ongoing for decades or even centuries, ferric iron precipitates are found as yellow-reddish precipitates onto waste rock surfaces or in nearby ditches. Depending on the chemical composition of the leachates, precipitated phases would be ferrihydrite $\left(\mathrm{Fe}(\mathrm{OH})_{3}\right)$, goethite $(\mathrm{FeOOH})$, jarosite $\left((\mathrm{K}, \mathrm{Na}, \mathrm{H}) \mathrm{Fe}_{3}\left(\mathrm{SO}_{4}\right)_{2}(\mathrm{OH})_{6}\right)$, melanterite $\left(\mathrm{FeSO}_{4} \cdot 7 \mathrm{H}_{2} \mathrm{O}\right)$ or schwertmannite $\left(\mathrm{Fe}_{8} \mathrm{O}_{8}(\mathrm{OH})_{6} \mathrm{SO}_{4}\right)$. Jarosite and schwertmannite are the most frequently reported phases in waters with low $\mathrm{pH}$ and high sulphate concentrations. Jarosite precipitates in strongly acidic environments $(\mathrm{pH}<\approx 2.5)[2]$ whereas schwertmannite is formed under less acidic conditions $(2.8<\mathrm{pH}<3.2)$ and is generally the mineral favoured to precipitate at this $\mathrm{pH}$ and high redox conditions [3]. There is a latent acidity coupled with continued weathering and de-watering of these basic ferric sulphate minerals as all eventually will be converted to goethite [4].

Generation of ferric iron can also lead to increased weathering of the sulphides still present in the waste rock deposit. Equations (5) and (6) below illustrate the weathering of pyrite (Equation (5)) and pyrrhotite (Equation (6)) driven by ferric iron-mechanisms that are highly acid producing.

$$
\begin{gathered}
\mathrm{FeS}_{2}+14 \mathrm{Fe}^{3+}+8 \mathrm{H}_{2} \mathrm{O} \rightarrow 15 \mathrm{Fe}^{2+}+2 \mathrm{SO}_{4}^{2-}+16 \mathrm{H}^{+} \\
\mathrm{Fe}_{0.9} \mathrm{~S}(\mathrm{~s})+7.8 \mathrm{Fe}^{3+}+4 \mathrm{H}_{2} \mathrm{O} \rightarrow 8.7 \mathrm{Fe}^{2+}+\mathrm{SO}_{4}^{2-}+8 \mathrm{H}^{+}
\end{gathered}
$$

Worth mentioning in this aspect is that Equation (5) and Equation (6) are processes that are able to proceed even when oxygen availability is gone, e.g. by remediation actions. Studies of a pre-oxidized sulphidic waste rock dump in Bersbo, Östergötland (mid-south Sweden) showed that almost 20 years after covering there was still ferric iron driven weathering of sulphides in the dump [5].

The sulphides sphalerite (Equation (7)), galena (Equation (8)) and chalcopyrite (Equation (9)) do not produce acid when oxidized, unless oxidation of chalcopyrite is driven by ferric iron (Equation (10)). However, when oxidized and dissolved in acidic solutions, these minerals mobilize free metal ions which will follow the flow of infiltrating water through and out of the pile. If buffering minerals in the pile are depleted, outflowing water will be acidic and contain dissolved metals.

$$
\begin{aligned}
& \mathrm{ZnS}(\mathrm{s})+2 \mathrm{O}_{2} \rightarrow \mathrm{Zn}^{2+}+\mathrm{SO}_{4}^{2-} \\
& \mathrm{PbS}(\mathrm{s})+2 \mathrm{O}_{2} \rightarrow \mathrm{Pb}^{2+}+\mathrm{SO}_{4}^{2-}
\end{aligned}
$$




$$
\begin{gathered}
\mathrm{CuFeS}_{2}(\mathrm{~s})+4 \mathrm{O}_{2} \rightarrow \mathrm{Cu}^{2+}+\mathrm{Fe}^{2+}+2 \mathrm{SO}_{4}^{2-} \\
\mathrm{CuFeS}_{2}(\mathrm{~s})+16 \mathrm{Fe}^{3+}+8 \mathrm{H}_{2} \mathrm{O} \rightarrow \mathrm{Cu}^{2+}+17 \mathrm{Fe}^{2+}+2 \mathrm{SO}_{4}^{2-}+16 \mathrm{H}^{+}
\end{gathered}
$$

Neutralizing or buffering mechanisms when acidic mine leachates meet a neutral environment mainly consist of a series of mineral dissolution and precipitation reactions which control and regulate $\mathrm{pH}$ and thus also the mobility of metals [6]. Primarily, carbonate minerals like calcite $\left(\mathrm{CaCO}_{3}\right)$, dolomite $\left(\mathrm{CaMg}\left(\mathrm{CO}_{3}\right)_{2}\right)$ and possibly also siderite $\left(\mathrm{FeCO}_{3}\right)$ dissolve and regulate $\mathrm{pH}$, which usually ends up at $\mathrm{pH}$ 6. In the event of equilibrium with calcite, $\mathrm{pH}$ will be around 7 and 8. Calcite can neutralize one proton (in the $\mathrm{pH}$-span 6 - 9) or two protons $(\mathrm{pH}<$ 6). Carbonates react fast and neutralize the acid as it is generated in the weathering processes.

When carbonate minerals are depleted, $\mathrm{pH}$ is regulated by iron- and aluminumoxyhydroxides (for example ferrihydrite $\left(\mathrm{Fe}(\mathrm{OH})_{3}\right)$ and gibbsite $\left(\mathrm{Al}(\mathrm{OH})_{3}\right)$, which involves a lowering of $\mathrm{pH}$ to around 4 [6]. Aluminium hydroxides generally buffer $\mathrm{pH}$ between 3.7 - 4.4 while iron hydroxides buffer between $\mathrm{pH} 3.3$ - 3.7.

When the iron- and aluminumoxyhydroxides are also depleted, $\mathrm{pH}$ will be defined by silicate minerals buffering, like olivine, biotite and chlorite, which means that $\mathrm{pH}$ will drop below 2 . Biotite and chlorite neutralize acid according to Equation (11) and Equation (12) respectively.

$$
\begin{gathered}
\mathrm{K}(\mathrm{Mg}, \mathrm{Fe})_{3} \mathrm{AlSi}_{3} \mathrm{O}_{10}(\mathrm{OH})_{2}(\mathrm{~s})+7 \mathrm{H}^{+} \rightarrow \mathrm{K}^{+}+3(\mathrm{Mg}, \mathrm{Fe})+\mathrm{Al}(\mathrm{OH})_{3}+3 \mathrm{SiO}_{2}+3 \mathrm{H}_{2} \mathrm{O} \\
\mathrm{Mg}_{5} \mathrm{Al}_{2} \mathrm{Si}_{3} \mathrm{O}_{10}(\mathrm{OH})_{8}(\mathrm{~s})+16 \mathrm{H}^{+} \rightarrow 5 \mathrm{Mg}^{2+}+2 \mathrm{Al}^{3+}+3 \mathrm{H}_{4} \mathrm{SiO}_{4}+6 \mathrm{H}_{2} \mathrm{O}
\end{gathered}
$$

However, weathering of for instance biotite is approximately $10^{7}$ and $10^{4}$ times slower than the weathering of calcite and pyrrhotite, respectively [7]. Hence, buffering from silicate minerals only plays a small role in the initial stages of weathering.

Aluminosilicate weathering, for example K-feldspar (Equation (13)), is often a sum of different parallel processes (i.e. the dissolution is often incongruent). The reactions generate precipitation of clay minerals and increase concentrations of base cations (sodium, potassium, calcium and magnesium) and aluminium in the solution.

$$
2 \mathrm{KAlSi}_{3} \mathrm{O}_{8}(\mathrm{~s})+2 \mathrm{H}^{+}+9 \mathrm{H}_{2} \mathrm{O} \rightarrow 2 \mathrm{~K}^{+}+\mathrm{Al}_{2} \mathrm{Si}_{2} \mathrm{O}_{5}(\mathrm{OH})_{4}(\mathrm{~s})+4 \mathrm{H}_{4} \mathrm{SiO}_{4}
$$

Geochemical calculations are important tools to understand the chemical evolution of contaminated water from the source to the receptor [8] [9]. Multivariate statistics are also tools that can be used to understand flow and evolution of the contaminated water. It has for instance been shown that principal component analysis (PCA) can be used to study the behaviour of trace elements in mining waste [10] and to characterize groundwater [11]. The aim of this paper is to try and identify seepage points and/stormwater drains releasing acid rock drainage from the mining site into the recipient using a combination of multivariate statistics and geochemical calculations.

\section{Materials and Methods}

\subsection{Field Site}

The mining site is located in the central part of the town of Kopparberg (“Copper Mountain”) in south central Sweden. Mining at the site started in 1624 and ceased in 1975. Mining was primarily for copper, but also lead, zinc and iron. There is roughly 30 water filled open pits/openings at the mining site. Depth of the underground workings varies, depending on age, from around $20 \mathrm{~m}$ to as deep as $460 \mathrm{~m}$ below the surface. The mining sitealso contains a large number of small waste rock deposits with varying age (a total volume of waste rock estimated at 200,000 $-300,000 \mathrm{~m}^{3}$ ). A large fraction of the waste rock is strongly weathered and releases trace elements into the environment. "Historical" mining waste is mostly vegetated while the "younger waste" lacks vegetation. Investigations performed in 2003 and 2005 indicated very high concentrations of $\mathrm{Cu}, \mathrm{Pb}$ and $\mathrm{Zn}$ in the waste rock. Also strongly contaminated groundwaters and seepage waters were noted as well as contaminated groundwater reaching the river Garhytteån. There is also a "Day opening" (a horizontal tunnel into the mine) releasing water from the underground workings into the town.

Waste piles at the historical mining site have been created through mining of a geologically very heterogeneous ore body during nearly 400 years of technical development. This has resulted in a rather chaotic situation 
where the properties of each waste pile are determined by a combination of historical and geological factors (e.g. metal prices, mining technique and grade cut off). Another factor is the fact that period of production introduces the factor of time with respect to weathering, leaching, recovery and development of vegetation.

Fire setting was probably used as mining method until late $18^{\text {th }}$ century, maybe even during the early parts of the $19^{\text {th }}$ century. Fire setting creates thin flakes of rock with a lot of fine cracks. Usually waste rock from fire setting is seldom more than a few centimeters thick and a few decimeters long. Waste rock produced from fire setting is probably more prone to weathering accelerating the decomposition of the waste rock.

Gun powder and dynamite blasting produce a coarse waste rock. Hand loading of the rock put a limit to the waste rock size. Dynamite blasting in machine drilled holes and increased mechanization in the mine gradually increased the size of the waste rock.

Techniques used in the mine during the years have varied and thus also the content in the waste dumps. During the $17^{\text {th }}$ century until early $20^{\text {th }}$ century only hand sorting was used. This method can only handle rich solid ores with a size suitable for hand sorting.

\subsection{Mapping and Sampling}

The mining site was thoroughly mapped for a lot of different parameters. For methods and discussions of the results the reader is referred to [12]. The field site was divided into 237 sub areas according to the appearance of the waste dumps and the current land use (waste dumps, industrial use, woods etc). According to the inspection of the sub areas 111 out of the 237 were considered to be mainly waste rock and suitable for sampling. Composite samples were collected mainly from the surface through handpicking for each sub area. A small part of every piece of rock was chipped off and added to the composite sample. Every composite sample consisted of approximately 35 - 35 pieces and weighed around $3-5 \mathrm{~kg}$. 105 of the composite samples were sent for analysis with respect to trace element concentrations.

16 groundwater wells were also sunk at the mining site, mostly using rotational drilling and steel casings with HDPE pipes (OD $63 \mathrm{~mm}$ ) in the center. Groundwaters were sampled using bailers after emptying the groundwater wells the day before in order to ensure fresh samples. Seepage and surface waters were also sampled regularly (see Figures 1-3). All sampling was performed using cleaned plastic bottles.

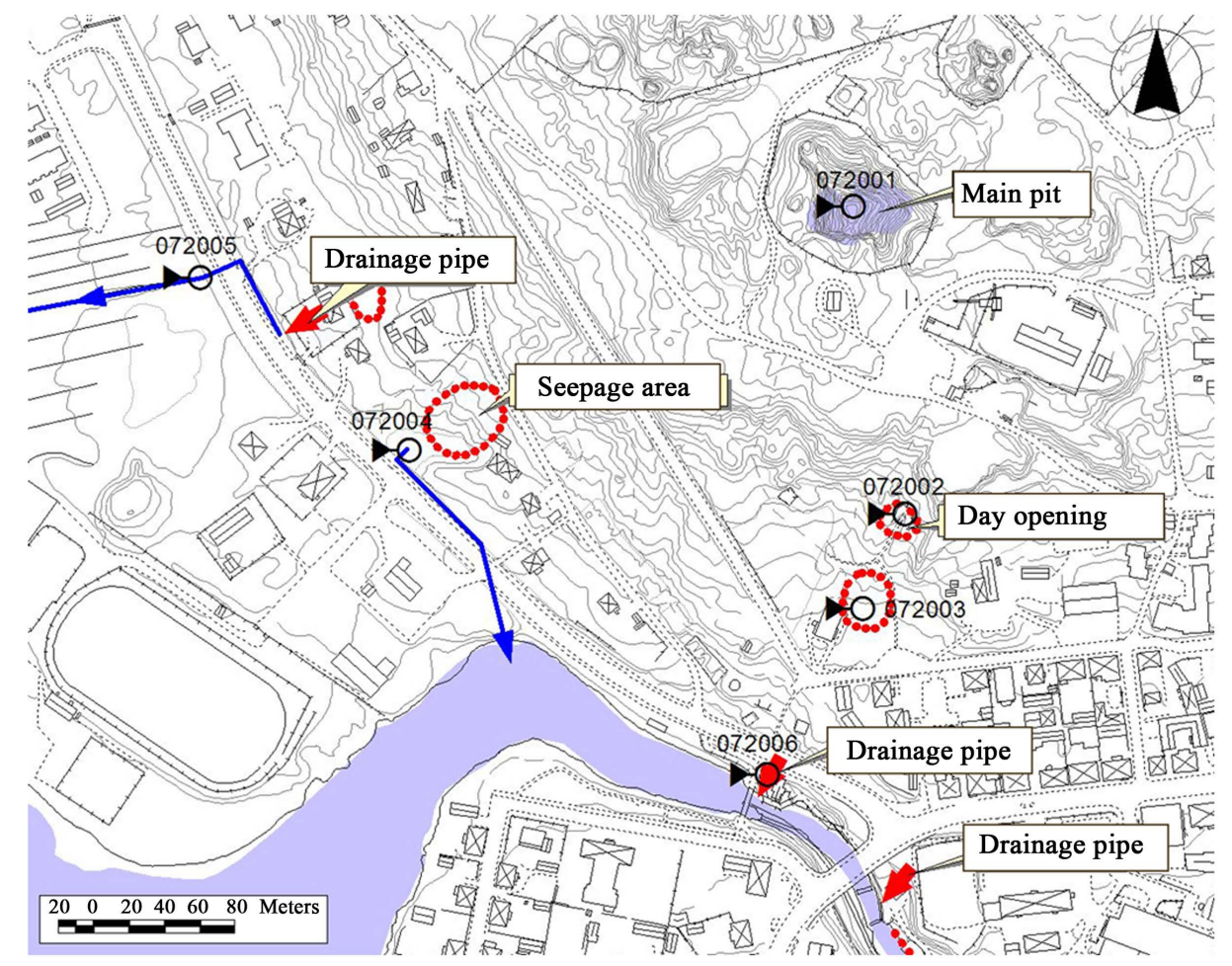

Figure 1. Mining site with major seepage areas and drainage pipes marked. 


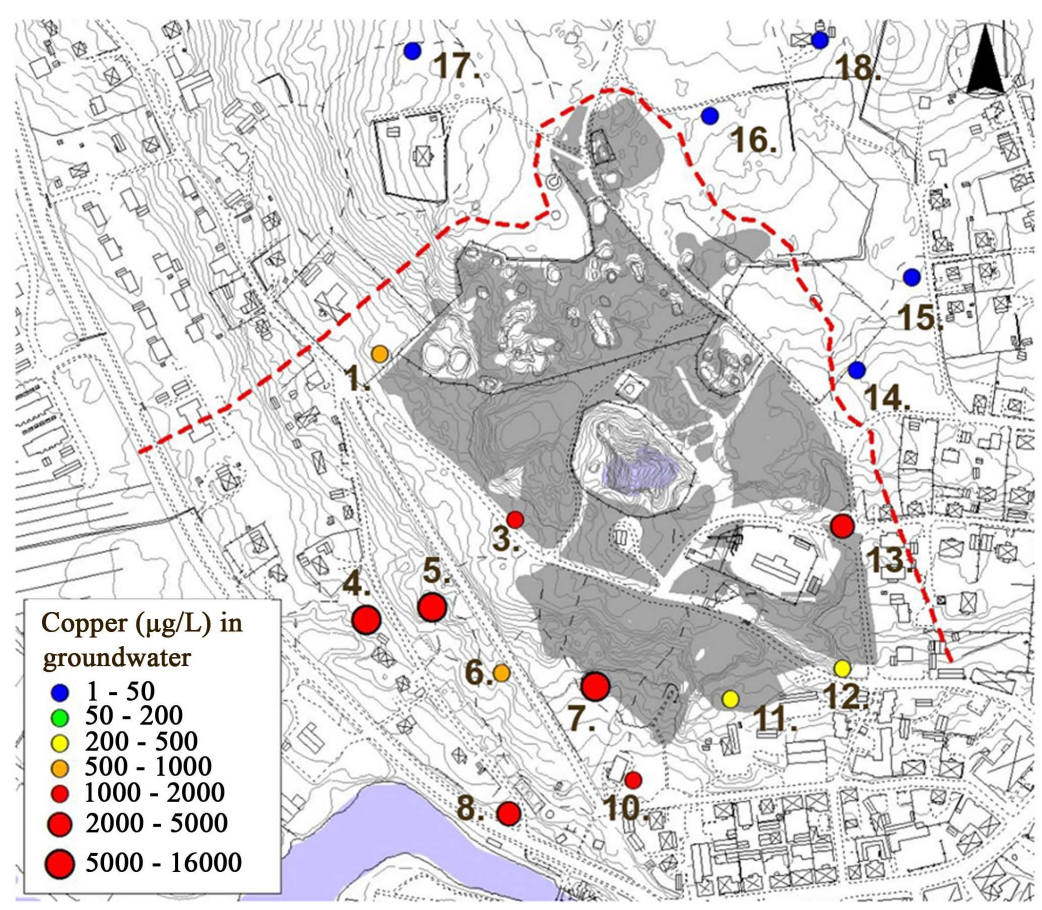

Figure 2. Copper concentrations in groundwater at the mining site. Red dotted line indicate the area affected by contaminated groundwater. Groundwater flow is towards the south and towards the southwest in the northern parts of the area.

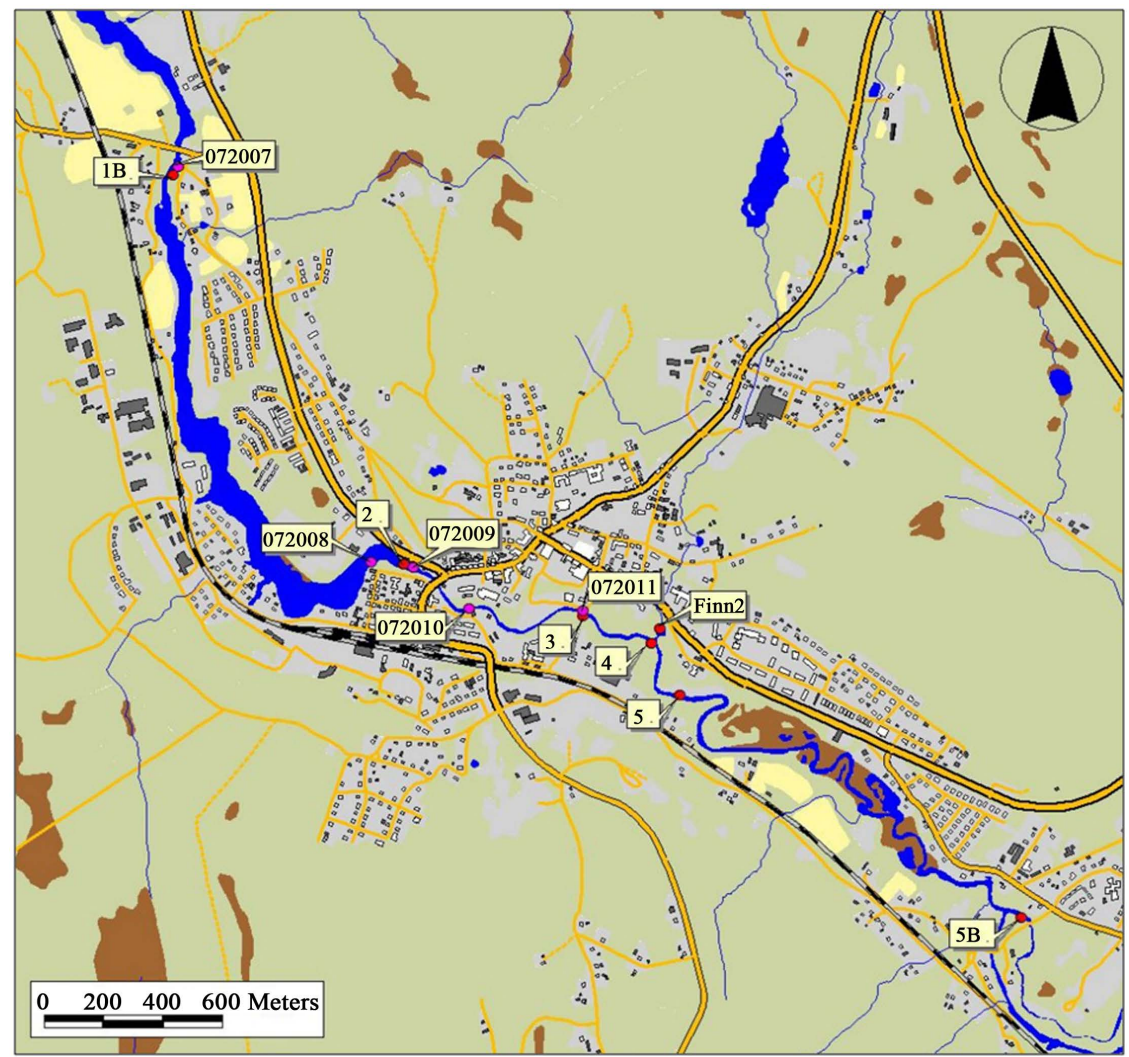

Figure 3. Bergskraft sample points for surface waters in river Garhytteån. 6014 is found 8 km upstream and sample point $60309 \mathrm{~km}$ downstream the mining site along the river. 


\subsection{Chemical Analysis}

Characterization of waste rock (105 samples) was perfomed with respect to total concentrations of trace elements (As, Cd, Co, Cr, Cu, Hg, Ni, Pb, V and Zn). Samples were digested using concentrated nitric acid in a closed micro wave oven and analysed for trace elements using ICP-MS by an accredited laboratory. This method does not provide a true total concentration, but provide a good estimate of the available concentrations.

A selection (10 samples) of waste rock samples were also analyzed for mineralogical content using XRD. Acid-base properties were also determined using acid-base-accounting. Sequential extraction was also performed on the same 10 samples in order to study the association of trace elements to the solid matrix. A modified four-step sequential extraction procedure by Tessier et al. [13] with modification by Karlsson et al. [14] was employed to fractionate the trace elements into exchangeable, acid soluble, reducible, oxidizable and residual fractions. Details of each step are reported in Table 1. After each leaching step, leachates were centrifuged at 20,000 g for 30 minutes. Residual fraction was calculated as the difference between total digestion and the sum of the used three fractions. All leachates were analyzed for elements using ICP-MS (Agilent 4500) using ${ }^{103} \mathrm{Rh}$ as internal standard.

Groundwaters, seepage and surface waters were analysed for physico-chemical parameters as well as elements by an external accredited laboratory. All water samples were filtered $(0.40 \mu \mathrm{m})$ and acidfied $(1 \%$ $\mathrm{HNO}_{3}$ ) prior to elemental analysis using methods EPA 200.7 (ICP-AES) and EPA 200.8 (ICP-MS). Reported precision for all analysis is between $5 \%$ and $10 \%$. Detection limits are not reported but is not a problem due to the relatively high concentrations in the area. Only arsenic (detection limit $1 \mu \mathrm{g} / \mathrm{L}$ ) and chromium (detection limit $0.5 \mu \mathrm{g} / \mathrm{L}$ ) have been found at concentrations below the used detection limits.

\subsection{Geochemical Calculations}

Chemical speciation was calculated for all groundwaters and seepage waters, using the geochemical code PHREEQC (version 3.3.2) [15] with the MINTEQ.v4 database. Expected solid phases were assessed, as well as saturation indices (SI; the ratio between the ion activity product and the solubility constant). Positive SI ( $>0.5$ ) indicates super saturation, negative SI $(<0.5)$ indicates sub saturation and SI in the range -0.5 to 0.5 was considered to represent equilibrium with the specific solid phase.

\subsection{Multivariate Statistics}

Water data was analysed using principal component analysis (PCA) with the chemometric software "The Unscrambler". Principal component analysis (PCA) was performed on all groundwaters, seepage and surface water samples (27 samples); basic parameters, 22 elements, anions (in total 35 parameters). Prior to the calculations all parameters were autoscaled and logarithmically transformed (except for $\mathrm{pH}$ ).

\section{Results and Discussion}

\subsection{Mapping}

From the ocular inspection of the samples it is apparent that the carbonate content is very low and that the sulfidic minerals are dominating over skarn minerals followed by almost equal amounts of fine grained silicate rock, micas and magnetite. Fluorite $\left(\mathrm{CaF}_{2}\right)$ is common in the waste rock.

Table 1. Sequential extraction method used for leaching of the waste rock. In the present investigations only steps 2-4 were used. Step 1 was not used since the intial $\mathrm{pH}$ was already below 7 and the residual was calculated as the difference between total concentrations and the sum of fractions $2-4$.

\begin{tabular}{|c|c|c|}
\hline Step & Reagent & Treatment \\
\hline 1 & Ion exchangeable & $20 \mathrm{~mL} 1 \mathrm{M} \mathrm{NH}_{4} \mathrm{Ac}$ at $\mathrm{pH} 7$ adjusted with $\mathrm{NH}_{3}$, for $1 \mathrm{~h}$ at $25^{\circ} \mathrm{C}$. \\
\hline 2 & Acid soluble & $20 \mathrm{~mL} 1 \mathrm{M} \mathrm{NH}_{4} \mathrm{Ac}$ at pH 5 adjusted with $\mathrm{HAc}$, for $5 \mathrm{~h}$ at $90^{\circ} \mathrm{C}$. \\
\hline 3 & Reducible & $20 \mathrm{~mL} 0.043 \mathrm{M} \mathrm{NH}_{2} \mathrm{OH}-\mathrm{HCl}$ in $25 \% \mathrm{HAc}$ for $5 \mathrm{~h}$ at $90^{\circ} \mathrm{C}$. \\
\hline 4 & Oxidizable & $20 \mathrm{~mL} 0.02 \mathrm{M} \mathrm{HNO}_{3}$ and $30 \% \mathrm{H}_{2} \mathrm{O}_{2}(3 / 5 \mathrm{v} / \mathrm{v})$ at $\mathrm{pH}$, adjusted with $\mathrm{HNO}_{3}$, for $3 \mathrm{~h}$ at $85^{\circ} \mathrm{C}$. \\
\hline 5 & Residual & Digestion in a closed micro wave oven using concentrated nitric acid. \\
\hline
\end{tabular}


It is also apparent that chalcopyrite is the dominating sulfidic mineral over both sphalerite and galena while sphalerite is slightly more abundant than galena. The distribution between pyrite and pyrrhotite, on the other hand, seems to be equal. Mapping of the mining waste indicated that large parts were significantly weathered. For instance, iron oxide and zinc hydroxide weathering was noted. In some cases weathering was noted to be so rapid that fresh material was continuously exposed.

\subsection{Element Content and Mineralogy}

According to the results in Table 2 elevated concentrations of primarily lead, zinc, copper and cadmium were found in the waste rock. Distribution of the trace elements across the mining site can be found in [12].

XRD-analysis (11 samples) showed that $42 \%$ quartz $\left(\mathrm{SiO}_{2}\right), 15 \%$ hornblende and $10 \%$ phlogopite $\left(\mathrm{KMg}_{3}\left[(\mathrm{OH})_{2} \mathrm{AlSi}_{3} \mathrm{O}_{10}\right]\right.$ were the dominating minerals in almost all waste rock samples. In addition to the major minerals a lot of alumino silicates (albite, anortite, muscovite) were present as well as several sulfides (pyrite, pyrrhotite, chalcopyrite, sphalerite). In the more weathered samples the mineral content of for instance gypsum $\left(\mathrm{CaSO}_{4}\right)$, goethite $(\mathrm{FeOOH})$ and jarosite $\left(\mathrm{KFe}_{3}\left(\mathrm{SO}_{4}\right)_{2}(\mathrm{OH})_{6}\right)$ were clearly enhanced compared to the unaltered samples.

\subsection{Acid-Base Accounting}

Rinse $\mathrm{pH}$ was found to be between 3.1 and 5.4 in the weathered mining waste samples indicating a release of acid rock drainage. Sulfide content was on average $0.9 \%$ with the highest value around $4.6 \%$. Neutralizing potential was found to be very low (average $6 \mathrm{~kg} \mathrm{CaCO}_{3} /$ ton), due to the very low content of carbonate minerals in the mining waste. Net neutralizing potential was found to be negative in almost all samples (average -20 , range -143 to $5 \mathrm{~kg} \mathrm{CaCO}_{3} /$ ton) confirming the acid drainage forming potential from the mining waste.

\subsection{Sequential Extraction}

In this kind of material it is reasonable to believe that the reducing step releases elements associated to iron oxyhydroxides and the oxidizing step releases elements associated to amorphous sulfides or organic matter. Residual fraction represents elements occluded within sparingly soluble minerals such as silicates and consolidated sulfides.

Around $10 \%$ of the iron was released during the reducing step (data not shown), indicating that almost all of the leachable iron is associated with the reducible fraction (that is iron oxyhydroxides found in weathering products). Leachability of trace elements $(\mathrm{Cd}, \mathrm{Cu}, \mathrm{Pb}$ and $\mathrm{Zn})$ is presented as leachable concentrations in Table 3.

Table 2. Statistical compilation of trace elements in the waste rock (n 105) and in till (background concentrations) (mg/kg dw).

\begin{tabular}{cccccccc}
\hline & Min & Median & Average & Max & $75:$ e perc & 95:e perc & Till (average) \\
\hline As & 0.13 & 0.41 & 0.53 & 1.75 & 0.72 & 1.26 & 0.83 \\
$\mathrm{Cd}$ & 0.02 & 3.25 & 19.5 & 251 & 20.4 & 92.8 & 0.06 \\
$\mathrm{Co}$ & 1.10 & 8.49 & 19.6 & 481 & 17.7 & 48.7 & 2.04 \\
$\mathrm{Cr}$ & 0.98 & 3.47 & 6.12 & 45.8 & 5.30 & 28.7 & 9.06 \\
$\mathrm{Cu}$ & 245 & 2560 & 3500 & 21,800 & 4290 & 9810 & 29.6 \\
$\mathrm{Hg}$ & 0.04 & 0.12 & 0.16 & 0.83 & 0.19 & 0.42 & $<0.04$ \\
$\mathrm{Ni}$ & 0.29 & 0.88 & 1.22 & 12.0 & 1.35 & 2.39 & 3.29 \\
$\mathrm{~Pb}$ & 6.92 & 276 & 3010 & 70,800 & 2100 & 15,700 & 9.43 \\
$\mathrm{~V}$ & 0.62 & 2.56 & 4.75 & 34.2 & 4.87 & 18.5 & 18.3 \\
$\mathrm{Zn}$ & 41.3 & 1840 & 8630 & 105,000 & 10,100 & 42,500 & 23.6 \\
\hline
\end{tabular}


Table 3. Leachability (mg/kg dw) from the sequential extraction during acid ( $\mathrm{pH} 5)$, reducing and oxidizing conditions for cadmium, copper, lead and zinc. Weath marks weathered samples.

\begin{tabular}{|c|c|c|c|c|c|c|c|c|c|c|c|c|}
\hline \multirow{2}{*}{ Sample } & \multicolumn{3}{|c|}{$\mathrm{Cd}$} & \multicolumn{3}{|c|}{$\mathrm{Cu}$} & \multicolumn{3}{|c|}{$\mathrm{Pb}$} & \multicolumn{3}{|c|}{$\mathrm{Zn}$} \\
\hline & Acid & Red & Ox & Acid & Red & Ox & Acid & Red & Ox & Acid & Red & Ox \\
\hline 071001, $1 \mathrm{~m}$ & 0.70 & 0.21 & 0.75 & 83.5 & 7.86 & 1290 & 167 & 72.0 & 13.3 & 44.8 & 25.3 & 368 \\
\hline 071001, 1 m, weath & 2.98 & 0.57 & 2.99 & 1200 & 36.4 & 5570 & 165 & 293 & 11.0 & 164 & 44.8 & 377 \\
\hline 071002, 0 - $1 \mathrm{~m}$ & 0.21 & 0.15 & 0.16 & 214 & 6.16 & 408 & 19.6 & 7.53 & 1.08 & 44.0 & 40.0 & 13.0 \\
\hline 071002, 0 - $1 \mathrm{~m}$, fine & 0.99 & 0.24 & 0.21 & 1420 & 13.2 & 600 & 167 & 67.8 & 13.1 & 187 & 85.9 & 19.4 \\
\hline 071003, 1 - $2 \mathrm{~m}$ & 0.23 & 0.14 & 0.79 & 46.7 & 7.25 & 520 & 8.28 & 9.67 & 0.87 & 47.6 & 33.7 & 202 \\
\hline 071003, 1 - $2 \mathrm{~m}$, weath & 0.33 & 0.16 & 0.20 & 36.5 & 18.4 & 154 & 15.0 & 30.1 & 1.52 & 49.2 & 30.8 & 9.61 \\
\hline 071007 & 0.18 & 0.14 & 0.19 & 81.9 & 8.32 & 563 & 60.3 & 46.8 & 3.24 & 27.6 & 18.4 & 10.9 \\
\hline 071007, weath & 0.18 & 0.16 & 0.22 & 175 & 300 & 283 & 160 & 288 & 29.2 & 28.7 & 23.0 & 19.4 \\
\hline 071008 & 0.14 & 0.11 & 0.35 & 31.9 & 7.96 & 1190 & 35.7 & 27.4 & 3.16 & 6.89 & 6.12 & 67.7 \\
\hline 071008, weath & 0.17 & 0.15 & 0.26 & 79.5 & 26.5 & 474 & 110 & 175 & 20.6 & 5.68 & 6.24 & 20.2 \\
\hline
\end{tabular}

Leachability of copper at $\mathrm{pH} 5$ was high, indicating that a large fraction of copper is loosely associated (sorption, precipitation, co-precipitation) to weathering products. This was also confirmed by the fact that the highest leachable concentrations were found in fines and weathered samples. A large pool of copper was thus very mobile during present conditions.

Leachability during reducing conditions was generally low compared to the total concentrations for all elements and samples. It is possible that most of the elements are already desorbed from the reducible phases (e.g. iron oxyhydroxides) due to the low $\mathrm{pH}$. During the reducible step leachability was greater from the weathered samples than from the unaltered samples. This is expected since this step primarily attacks oxidized secondary minerals.

Leachability during oxidizing conditions was clearly higher than during reducing conditions. This indicates that a significant fraction of the total concentration still remain as sulfides in the samples. This was especially clear for copper, where roughly $25 \%$ - 55\% of the total concentrations was leached during oxidizing conditions depending on whether the samples were weathered or not. The results indicate that there is a large remaining leachable reservoir in the unweathered mining waste (on average $56 \%$ and $23 \%$ of the total concentrations for copper and zinc, respectively). It is primarily unweathered samples that have a large fraction still available for oxidizable leaching, indicating that the elements are still associated with sulfides. In general, the leachability for copper during oxidizing conditions is higher in unweathered samples.

From Table 3 it is clear that the leaching pattern was different for different elements; copper had higher leachability during oxidizing conditions compared to lead, that had higher leachability during reducing conditions and leaching at $\mathrm{pH}$ 5. Zinc showed significant leaching under reducing conditions, but also during the other leaching steps.

The primary contaminant in the waste rock is copper with high leachability both at $\mathrm{pH} 5$ and during oxidizing conditions (Table 4). This indicates that there is both an immediately available pool of leachable copper (probably associated to or adsorbed on secondary minerals) and a large future leaching potential through further oxidation (elements still in sulfide form).

\subsection{Groundwaters and Seepage Waters}

In Table 5 a compilation of concentrations in both unaffected and affected groundwaters can be found. It is clear from the composition of the groundwaters that affected groundwaters have elevated concentrations of primarily aluminum and copper compared to less affected groundwaters (Table 5). Also cadmium, cobalt, zinc, sulfate, fluoride and iron were found in considerably higher concentrations. This together indicate weathering of, for instance, pyrite with lowered $\mathrm{pH}$ and increased sulfate and iron concentrations as a result. Lowered $\mathrm{pH}$ leads to 
Table 4. Average leachability (mg/kg dw) for cadmium, copper, lead and zinc during the different leaching steps.

\begin{tabular}{ccccc}
\hline & $\mathrm{Cd}$ & $\mathrm{Cu}$ & $\mathrm{Pb}$ & $\mathrm{Zn}$ \\
\hline pH 5 average & 0.61 & 337 & 90.8 & 60.6 \\
Reducing average & 0.20 & 43.2 & 102 & 31.4 \\
Oxidizing average & 0.61 & 1110 & 9.71 & 111 \\
\hline
\end{tabular}

Table 5. Statistical compilation of concentrations in mining water, ditch water, storm water and groundwaters. All samples were filtered.

\begin{tabular}{|c|c|c|c|c|c|c|c|c|c|c|c|}
\hline & \multicolumn{4}{|c|}{ Mine water } & \multicolumn{3}{|c|}{ Ditch-/storm water } & \multicolumn{2}{|c|}{$\begin{array}{c}\text { Affected } \\
\text { ground-water } 1 \text { - } 13\end{array}$} & \multicolumn{2}{|c|}{$\begin{array}{c}\text { Unaffected } \\
\text { ground-water } 14 \text { - } 18\end{array}$} \\
\hline & Unit & 072001 & 072002 & 072003 & 072004 & 072005 & 072006 & Median & Average & Median & Average \\
\hline $\mathrm{Ca}$ & $\mathrm{mg} / \mathrm{L}$ & 142 & 204 & 207 & 85.3 & 66.6 & 145 & 72.2 & 78.7 & 12.8 & 31.8 \\
\hline $\mathrm{Mg}$ & $\mathrm{mg} / \mathrm{L}$ & 44.7 & 50.3 & 50.5 & 32.2 & 20.6 & 34.7 & 14.5 & 20.3 & 1.86 & 3.44 \\
\hline $\mathrm{Na}$ & $\mathrm{mg} / \mathrm{L}$ & 6.35 & 9.46 & 9.46 & 6.23 & 13.3 & 14.5 & 6.00 & 6.94 & 2.21 & 2.13 \\
\hline $\mathrm{K}$ & $\mathrm{mg} / \mathrm{L}$ & 4.85 & 5.78 & 5.74 & 3.16 & 3.69 & 6.53 & 4.08 & 4.80 & 1.71 & 2.42 \\
\hline $\mathrm{Fe}$ & $\mathrm{mg} / \mathrm{L}$ & 1.59 & 16.1 & 15.3 & 0.24 & 0.48 & 0.38 & 0.20 & 2.74 & 0.02 & 0.20 \\
\hline $\mathrm{Al}$ & $\mathrm{mg} / \mathrm{L}$ & 23.8 & 15.3 & 14.9 & 28.6 & 9.31 & 33.0 & 11.7 & 15.0 & 0.082 & 0.40 \\
\hline Mn & $\mathrm{mg} / \mathrm{L}$ & 3.49 & 4.81 & 4.91 & 1.58 & 1.13 & 2.12 & 1.00 & 1.27 & 0.013 & 0.036 \\
\hline Turbidity & FNU & 0.38 & 75.5 & 106 & 4.3 & 33.5 & 84.5 & 175 & 438 & 11 & 41 \\
\hline El. Cond & $\mu \mathrm{S} / \mathrm{cm}$ & 1150 & 1350 & 1350 & 869 & 613 & 1140 & 689 & 671 & 120 & 201 \\
\hline $\mathrm{pH}$ & & 4.6 & 5.6 & 5.8 & 4.8 & 5.6 & 5.2 & 5.2 & 5.0 & 6.5 & 6.6 \\
\hline Alk. & $\mathrm{mg} \mathrm{HCO}_{3} / \mathrm{L}$ & $<1.0$ & 9.65 & 12 & $<1.0$ & 23 & $<1.0$ & 6.35 & 13.2 & 26.5 & 65.9 \\
\hline Sulphate & $\mathrm{mg} / \mathrm{L}$ & 684 & 421 & 422 & 517 & 294 & 674 & 325 & 345 & 19 & 23.2 \\
\hline As & $\mu \mathrm{g} / \mathrm{L}$ & $<1$ & 1.19 & $<1$ & $<1$ & $<1$ & $<1$ & $<1$ & $<1$ & $<1$ & $<1$ \\
\hline $\mathrm{Cd}$ & $\mu g / L$ & 44.1 & 22.8 & 22.7 & 22.5 & 6.11 & 26.8 & 7.55 & 13.1 & 0.14 & 0.15 \\
\hline Co & $\mu \mathrm{g} / \mathrm{L}$ & 70.7 & 42.9 & 43.3 & 59.5 & 35.6 & 53.1 & 15.8 & 32.8 & 0.17 & 0.29 \\
\hline $\mathrm{Cr}$ & $\mu \mathrm{g} / \mathrm{L}$ & $<0.5$ & $<0.5$ & $<0.5$ & $<0.5$ & $<0.5$ & 2.53 & 0.97 & 0.97 & 0.62 & 0.62 \\
\hline $\mathrm{Cu}$ & $\mu \mathrm{g} / \mathrm{L}$ & 3430 & 2085 & 1825 & 12,800 & 5160 & 9310 & 2050 & 4330 & 16.7 & 18.5 \\
\hline $\mathrm{Ni}$ & $\mu \mathrm{g} / \mathrm{L}$ & 6.54 & 6.00 & 5.80 & 7.02 & 4.17 & 8.27 & 8.82 & 12.8 & 1.98 & 2.31 \\
\hline $\mathrm{Pb}$ & $\mu \mathrm{g} / \mathrm{L}$ & 384 & 470 & 292 & 531 & 2.98 & 88.6 & 4.21 & 13.9 & 0.56 & 0.60 \\
\hline $\mathrm{Zn}$ & $\mu \mathrm{g} / \mathrm{L}$ & 24,000 & 19,700 & 19,500 & 11,200 & 3310 & 14,200 & 4390 & 7700 & 47.6 & 94.7 \\
\hline
\end{tabular}

increased weathering of other sulfide minerals and silicates, thus leading to increased trace element and aluminum concentrations. Increased aluminum concentrations will also provide latent acidity able to lower the $\mathrm{pH}$ further down in the surface water system. Compared to other mining areas in the world concentrations of sulfate and iron are lower [16] [17], maybe reflecting the fact that the mining waste is almost 400 years old and the most reactive period has probably already passed. However, copper and zinc concentrations are comparable to other ARD quality data around the world.

Mining water has been sampled at the "Main pit" (sample point 072001), and in the outflow from the "Day opening" (sample point 072002). North east of sample point 072004 groundwater flows out. Groundwater is diverted towards the south east via a road ditch and through a culvert under the road towards the creek Garhytteån. The seepage point was sampled before the water enters the road ditch. Analytical results from 072001, 072002 
and 072004 clearly show an impact from leachate from the mining waste with high concentrations of sulfate, lead, cadmium, copper and zinc.

In Table 5 a comparison between the water in the "Main pit" and some seepage points are shown. At sample point 072005 , water was sampled in a road ditch. A drainage pipe from a seepage area also feeds the ditch. Analytical results here also show a clear impact from mining waste drainage with high concentrations of sulfate, lead, cadmium, copper and zinc. The concentrations are somewhat lower compared to sample point 072004, indicating some dilution, probably by road runoff since the chloride concentration is somewhat enhanced (15 $\mathrm{mg} / \mathrm{L}$ in 072005 compared to $5 \mathrm{mg} / \mathrm{L}$ in 072004).

Just upstream the road and creek crossing a drainage pipe is found, most probably a stormwater drain (sample point 072006). Also this water is probably affected by the mining site. Metal concentrations are typically as high as in 072004, but somewhat enhanced chloride and COD (data not shown) concentrations indicate an impact from stormwater runoff as well. In Table 5 there is a statistical compilation of concentrations in mining water, ditch water, storm water and groundwater.

Higher concentrations of calcium and magnesium in the mine water indicate neutralization processes with at least calcite and perhaps dolomite. Elevated concentrations of aluminum also indicate weathering of aluminosilicates [7]. A comparison between the water quality in the "Main pit" (072001) and in the "Day opening" (072002) indicates a change in water chemistry between the two points. Calcium and iron concentrations as well as $\mathrm{pH}$ is higher in the "Day opening" while for instance sulfate, fluoride and aluminum concentrations are lower. Since the samples from the "Main pit" are from the surface and the water from the "Day opening" is most likely not just from the "Main pit" a strict comparison might be difficult.

If, however, the apparent change in quality between the "Main pit" and the "Day opening" is true the results might indicate that the water along the route between the sample points is buffered by calcite $\left(\mathrm{CaCO}_{3}\right)$ or other buffering minerals in the underground workings. As a result of the increased calcium concentrations precipitation of gypsum $\left(\mathrm{CaSO}_{4}\right)$ and fluorite $\left(\mathrm{CaF}_{2}\right)$ can take place, thus reducing the sulfate and fluoride concentrations. The reason behind increased iron concentrations might be reductive dissolution of iron oxyhydroxides present in the underground workings. Since the underground workings today is below water (reducing conditions) no further oxidization of the sulfide minerals occur, keeping the $\mathrm{pH}$ from dropping.

\subsection{Surface Waters}

Samples have been taken regularly in the river Garhytteån by two monitoring programs (one by the county board and one by Bergskraft (see Figure 3)). Lead, cadmium, copper and zinc concentrations from the monitoring programs are presented in Table 6.

When comparing sample points 6014 and 6030 in the county board monitoring program it is obvious that zinc concentrations have increased one order of magnitude, lead with a factor of 8-9, copper and cadmium with a factor of 3-4. How much of the increase that the field site is responsible for is not possible to determine from these samples since the river between these two points passes through several other possibly contaminated sites.

Monitoring by Bergskraft has been performed at a lot more points and can thus give a more detailed picture about the trace element addition from the field site. In Table 6 average concentrations of lead, copper and zinc from the Bergskraft monitoring is presented.

Sample point 1B is positioned upstream the field site and can be considered a reference. From Table 6 it can be noted that the trace element concentrations increase between sample points $1 \mathrm{~B}$ and 2 (south of the field site).

Table 6. Average copper, lead and zinc concentrations (filtered) from the county board monitoring program (n 18) and Bergskraft sampling points (n 41 - 45) in the river Garhytteån. Concentrations in $\mu \mathrm{g} / \mathrm{L}$. Increased risk for biological effects at concentrations above $9 \mu \mathrm{g} / \mathrm{L}$ copper, $3 \mu \mathrm{g} / \mathrm{L}$ lead and $60 \mu \mathrm{g} / \mathrm{L}$ zinc [18].

\begin{tabular}{ccccccc}
\hline & $\begin{array}{c}6014 \\
\text { Upstream }\end{array}$ & $\begin{array}{c}1 \mathrm{~B} \\
\text { Upstream }\end{array}$ & $\begin{array}{c}2 \\
\text { At the dam }\end{array}$ & $\begin{array}{c}3 \\
\text { Around } 650 \mathrm{~m} \\
\text { downstream the dam }\end{array}$ & $\begin{array}{c}5 \\
\text { Around } 1 \mathrm{~km} \\
\text { downstream the dam }\end{array}$ \\
$\mathrm{Cu}$ & $\mu \mathrm{g} / \mathrm{L}$ & 0.95 & 1.9 & 2.6 & 3.3 & 4.7 \\
$\mathrm{~Pb}$ & $\mu \mathrm{g} / \mathrm{L}$ & 0.47 & 0.7 & 0.8 & 0.9 & 4.3 \\
$\mathrm{Zn}$ & $\mu \mathrm{g} / \mathrm{L}$ & 5.5 & 21 & 23 & 31 & 35 \\
\hline
\end{tabular}


All leachates from the field has probably not reached the river at sample point 2. At sample point 3 (around 650 $\mathrm{m}$ downstream the site) all leachates have probably reached the river. At this point copper concentration has increased $80 \%$, lead $40 \%$ and zinc $50 \%$ compared to the reference concentrations. Concentrations then increase further between sample point 3 and 5 (due to a tributary (marked "Finn 2" in Figure 3) from another mining site).

\subsection{Contaminant Flow}

There are several possible ways ARD can leave the mining site; surface runoff, soil groundwater, underground workings, bedrock groundwater and through stormwater runoff drainage pipes. Surface runoff has not been observed at the site. This is most likely due to the fact that formed runoff drains into the open pits and most likely are overflowed into the "Day opening". Soil groundwater are probably formed towards the river and seeps out at 072004 for instance. Deeper groundwater in the bedrock is probably not formed due to the presence of the underground workings, able to carry most water from the mining site. Several drainage pipes have been noted releasing water into the river.

\subsection{Flowpaths and Relationships between Sampling Points}

Principal component analysis (PCA) was used in order to investigate connections between groundwaters and surface waters as well as possible flow paths from the mining site. Results from the principal component analysis (PCA) of groundwaters and surface waters are found in Figure 4 and Figure 5.

The loading plot (Figure 5) shows the relationship between the analysed parameters in all waters. It is clear that parameters with high concentrations are found on the opposite side to $\mathrm{pH}$ in the first principal component (PC1) [19], indicating that these parameters can be found in the contaminated drainage. PC1 explains 63\% of the total variation of the data. It is also interesting to note that lead, turbidity and iron are found close to each other, indicating that lead possibly is transported associated to particles [20]. PC2 explains only 8\% of the data variation and it is mainly associated to parameters related to dissolved organic matter (color and COD).

The score plot (Figure 4) illustrates the relationship between the different samples. 072007, 072008, 072009 and 072011 have, for instance, high values in PC1 together with groundwaters 17 and 18. All six waters are either unaffected or only marginally affected by the polluted drainage. Waters with negative values in PC1 are for instance $072001,072002,072003$ and groundwater 4 . These waters are significantly affected by mining drainage, indicating that PC1 to some extent represent the fraction of contaminated drainage in the samples (i.e. dilution). Samples with high positive values in PC1 have a small fraction drainage water while samples with high negative values have a large fraction of drainage water in the sample.

It is also clear that 072005 and 072006 as well as 072004 are heavily affected by contaminated drainage water. Dilution as an important factor for evolution of groundwaters has been shown earlier [11]. From the relationship between the different surface waters and groundwaters from the PCA analysis (Figure 4 and Figure 5) probable water flowpaths from the mining site can be discussed. The first flow path consists of 072001 ("Main pit") that is altered chemically on the way through the underground workings to 072002 ("Day opening") and 072003 . It is also clear that 072006 (a drainage pipe into the creek) in principle consists of pure drainage water from the mining site (compare PC1 with 072002 and 072003). It is thus likely that this pipe funnels contaminated water from around the "Day opening" area to the recipient. Groundwater 4 also has a profile like the most contaminated waters from the mine. 072004 is then only a diluted groundwater 4 and 072005 after further dilution with non-contaminated water.

It is estimated that around $50 \%$ of the leachates from the mining site is infiltrated and released through the mine workings while the remaining $50 \%$ is soil groundwater. Total annual runoff from the mining site $(20-25$ ha) is approximately $80,000-100,000 \mathrm{~m}^{3} /$ year. Assuming copper and zinc concentrations in the interval 2000 $5000 \mu \mathrm{g} / \mathrm{L}$ copper and 5000 - 15,000 $\mu \mathrm{g} / \mathrm{L}$ zinc (Table 5) the annual transport is around 160 - $500 \mathrm{~kg} /$ year copper and $400-1500 \mathrm{~kg} /$ year zinc. Assuming that all this reaches the river $\left(3.8 \mathrm{~m}^{3} / \mathrm{s}\right)$ there are additional increases in concentrations for copper and zinc at $1-4 \mu \mathrm{g} / \mathrm{L}$ copper and $3-13 \mu \mathrm{g} / \mathrm{L}$ zinc, respectively. These additional concentrations should be compared with the increase in concentrations between sample points 1B and 3 (Table 6). The concentrations indicate that leaching of metals from the mining site is a possible explanation for the increase of metals in the river. 


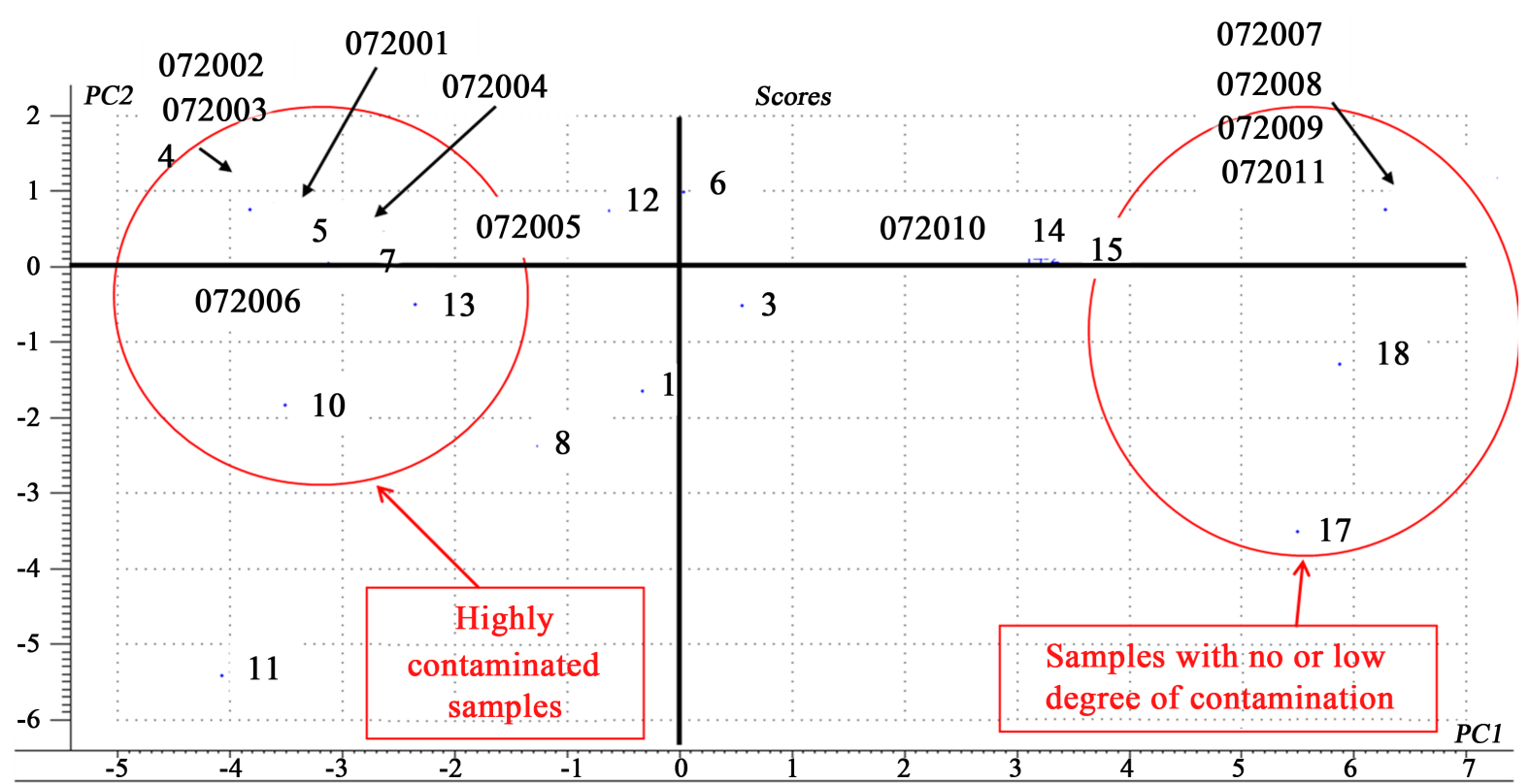

Grv+ytv log pca. X-expl: $63 \%, 8 \%$

Figure 4. Score plot from the principal component analysis. Samples clearly affected by contaminants at the left on PC1 while unaffected samples at the right on PC1. Groundwaters 1-18 and surface waters 072001-072011.

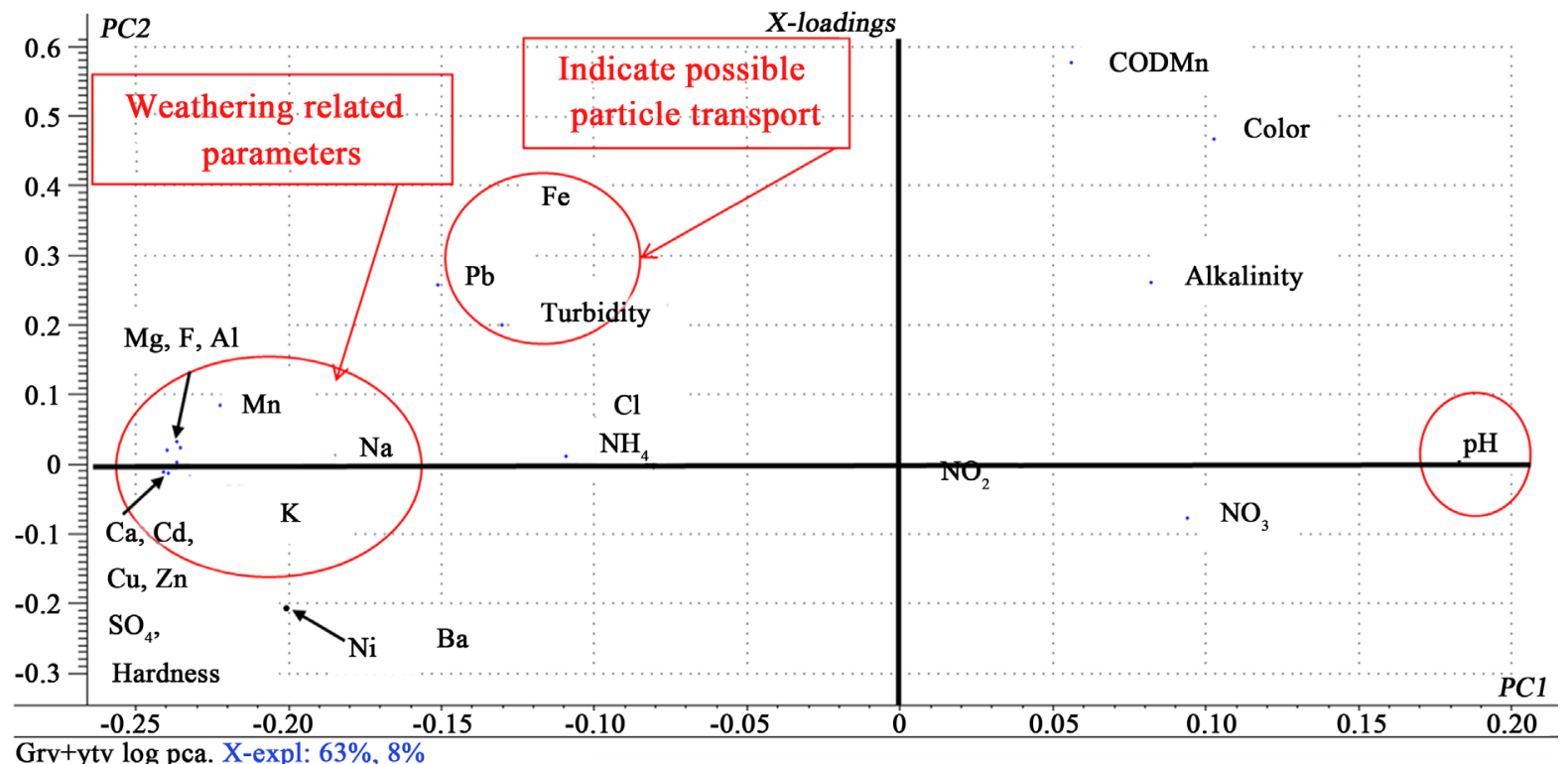

Figure 5. Loading plot from the principal component analysis. Weathering parameteras are tightly together far from pH. Relationship between iron, lead and tubidity indicate tha lead is likely transported on iron oxyhydroxide particles.

\section{Conclusions}

It has been shown that there are small amounts of sulfides left in the waste rock. Most waste rock is heavily weathered. There are, however, clearly enhanced levels of primarily copper, cadmium, lead and zinc in the waste rock. Large amounts of leachable elements are also left in the waste. This indicates that there is still a large pool of elements within the waste and a large fraction is immediately available for release to the recipient.

Using multivariate statistics (PCA) it was possible to indicate the most likely paths for the contaminated water to the recipient. The two major pathways for contaminated water at the mining site were found to be the "Day 
opening” through the underground workings funneling a lot of the water from the mining site and soil groundwater at the slope towards the river. Dilution was identified as the most important mechanism for the evolution of waters as opposed to immobilization and sorption. Dilution was represented by PC1 and explained $63 \%$ of the variation in the data material. Waters changed along the flowpaths through for instance dissolution of calcite followed by precipitation of gypsum and fluorite.

\section{Acknowledgements}

David Ekholm at SWECO Environment AB, Örebro, Sweden, is greatly acknowledged for providing information about water flows at the site.

\section{References}

[1] España, J.S., Pamo, E.L., Santofimia, E., Aduvire, O., Reyes, J. and Barettino, D. (2005) Acid Mine Drainage in the Iberian Pyrite Belt (Odiel River Watershed, Huelva, SW Spain): Geochemistry, Mineralogy and Environmental Implications. Applied Geochemistry, 20, 1320-1356. http://dx.doi.org/10.1016/j.apgeochem.2005.01.011

[2] Höglund, L.O., Herbert, R.B., Lövgren, L., Öhlander, B., Neretnieks, I., Moreno, L., Malmström, M., Elander, P., Lindvall, M. and Lindström, B. (2004) MiMi-Performance Assessment, Main Report.

[3] España, J.S., Pamo, E.L., Pastor, E.S., Andrés, J.R. and Rubi, J.A.M. (2006) The Removal of Dissolved Metals by Hydroxysulphate Precipitates during Oxidation and Neutralization of Acid Mine Waters, Iberian Pyrite Belt. Aquatic Geochemistry, 12, 269-298. http://dx.doi.org/10.1007/s10498-005-6246-7

[4] Bigham, J.M., Schwertmann, U., Traina, S.J., Winland, R.L. and Wolf, M. (1996) Schwertmannite and the Chemical Modeling of Iron in Acid Sulfate Waters. Geochimica et Cosmochimica Acta, 60, 2111-2121.

http://dx.doi.org/10.1016/0016-7037(96)00091-9

[5] Karlsson, S. and Bäckström, M. (2003) Surface Water Quality in Bersbo, Sweden-Fifteen Years after Amelioration of Sulphidic Waste. In: Mining and the Environment III, Sudbury, Canada (CD-ROM).

[6] Jurjovec, J., Ptacek, C.J. and Blowes, D.W (2002) Acid Neutralization Mechanisms and Metal Release in Mine Tailings: A Laboratory Column Experiment. Geochimica et Cosmochimica Acta, 66, 1511-1523. http://dx.doi.org/10.1016/S0016-7037(01)00874-2

[7] Banwart, S.A. and Malmström, M.E. (2001) Hydrochemical Modelling for Preliminary Assessment of Mine Water Pollution. Journal of Geochemical Exploration, 74, 73-97. http://dx.doi.org/10.1016/S0375-6742(01)00176-5

[8] Sartz, L., Bäckström, M., Karlsson, S. and Allard, B. (2015) Mixing of Acid Rock Drainage with Alkaline Leachates: Formation of Solid Precipitates and $\mathrm{pH}$ Buffering. Mine Water and the Environment, 1-13. http://dx.doi.org/10.1007/s10230-015-0347-3

[9] Mosley, L.M., Daly, R., Palmer, D., Yeates, P., Dallimore, C., Biswas, T. and Simpson, S.L. (2015) Predictive Modelling of $\mathrm{pH}$ and Dissolved Metal Concentrations and Speciation Following Mixing of Acid Drainage with River Water. Applied Geochemistry, 59, 1-10. http://dx.doi.org/10.1016/j.apgeochem.2015.03.006

[10] Yousefi, S., Ardejani, F.D., Ziaii, M., Abedi, A. and Zadeh, E.E. (2015) Investigating the Origin and Geochemical Behaviour of Toxic Elements within the Waste Dumps Using Statistical Analyses: A Case Study at Waste Dumps of Sarcheshmeh Copper Mine, SE of Iran. Environmental Earth Science, 73, 1555-1572. http://dx.doi.org/10.1007/s12665-014-3507-z

[11] Peng, K., Li, X. and Wang, Z. (2015) Hydrochemical Characteristics of Groundwater Movement and Evolution in the Xinli Deposit of the Sanshandao Gold Mine Using FCM and PCA Methods. Environmental Earth Science, 73, 78737888. http://dx.doi.org/10.1007/s12665-014-3938-6

[12] Bäckström, M. and Sädbom, S. (2008) Risk Assessment of Historical Mine Waste Using Chemical Analysis and Ocular Mineral/Rock Classification. Proceedings of the 9th International Congress for Applied Mineralogy, Australasian Institute of Mining and Metallurgy, Brisbane, 8-10September 2008, 85-90.

[13] Tessier, A. and Campbell, P. (1979) Partitioning of Trace Metals in Sediments: Relationships with Bioavailability. Hydrobiologia, 149, 43-52. http://dx.doi.org/10.1007/BF00048645

[14] Karlsson, S., Håkansson, K. and Allard, B. (1987) Simultaneous Dissolution of Organic Acids in Sequential Leaching of Sediment Bound Trace Metals. Journal of Environmental Science and Health, Part A: Environmental Science and Engineering, 22, 549-562. http://dx.doi.org/10.1080/10934528709375370

[15] Parkhurst, D.L. and Appelo, C.A.J. (2013) Description of Input and Examples for PHREEQC Version 3-A Computer Program for Speciation, Batch-Reaction, One-Dimensional Transport, and Inverse Geochemical Calculations. US Geological Survey Techniques and Methods, Book 6, Chapter A43, 497 p. http://pubs.usgs.gov/tm/06/a43 
[16] Hammarstrom, J.M., Seal II, R.R., Meier, A.L. and Kornfeld, J.M. (2005) Secondary Sulfate Minerals Associated with Acid Drainage in the Eastern US: Recycling of Metals and Acidity in Surficial Environments. Chemical Geology, 215, 407-431. http://dx.doi.org/10.1016/j.chemgeo.2004.06.053

[17] España, J.S., Pamo, E.L., Santofimia, E., Aduvire, O., Reyes, J. and Barettino, D. (2005) Acid Mine Drainage in the Iberian Pyrite Belt (Odiel River Watershed, Huelva, SW Spain): Geochemistry, Mineralogy and Environmental Implications. Applied Geochemistry, 20, 1320-1356. http://dx.doi.org/10.1016/j.apgeochem.2005.01.011

[18] Swedish Environmental Protection Agency (1999) Bedömningsgrunder för miljökvalitet. Sjöar och vattendrag. (Criterias for Environmental Quality. Lakes and Water Courses). Report 4913. (In Swedish)

[19] Parizi, H.S. and Samani, N. (2013) Geochemical Evolution and Quality Assessment of Water Resources in the Sarcheshmeh Copper Mine Area (Iran) Using Multivariate Statistical Techniques. Environmental Earth Science, 69, 16991718. http://dx.doi.org/10.1007/s12665-012-2005-4

[20] Resongles, E., Casiot, C., Freydier, R., Le Gall, M. and Elbaz-Poulichet, F. (2015) Variation of Dissolved and Particulate Metal(loid) (As, Cd, Pb, Sb, Tl, Zn) Concentrations under Varying Discharge during a Mediterranean Flood in a Former Mining Watershed, the Gardon River (France). Journal of Geochemical Exploration, 158, 132-142. http://dx.doi.org/10.1016/j.gexplo.2015.07.010 